\title{
ANALÝZA NEZAMĚSTNANOSTI POMOCI INSIGHTS FOR ARCGIS
}

\author{
Pavel KUKULIAČ ${ }^{1}$, Jiří HORÁK ${ }^{2}$ \\ ${ }^{1}$ Katedra geoinformatiky, Hornicko-geologická fakulta, 17. listopadu 2172/15, 708 00, Ostrava, \\ Česká republika \\ pavel.kukuliac@vsb.cz \\ ${ }^{2}$ Katedra geoinformatiky, Hornicko-geologická fakulta, 17. listopadu 2172/15, 708 00, Ostrava, \\ Česká republika \\ jiri.horak@vsb.cz
}

doi: https://doi.org/10.31490/9788024843988-14

\begin{abstract}
Abstrakt
Insights for ArcGIS je aplikace ESRI určená pro interaktivní analytickou práci s prostorovými daty pomocí map, grafů a tabulek. Pro potřeby MPSV byla připravena ukázka možnosti využití tohoto nástroje pro analýzy trhu práce. Na konkrétním příkladu je demonstrováno, jak byla aplikace připravena, jak probíhalo nastavení a jak pracuje finální ukázková implementace. Zatímco příprava tradičními postupy by byla časově náročná, předností nové aplikace je rychlost, snadnost a intuitivnost ovládání. Současně jsou diskutovány i možnosti variant řešení z hlediska nasazení typu aplikace (desktop, online, enterprise).
\end{abstract}

\begin{abstract}
Insights for ArcGIS is an ESRI application created for an interactive analysis of spatial data through maps, charts and tables. A demonstration of the application capabilities was prepared for the Ministry of Labour and Social Affairs (MoLSA) purposes. On a specific case study, it is presented the procedure of application settings and preparation, and the functionality of final case study implementation. Data preparation by traditional methods is often time consuming, the benefits of this new application, in compared to the traditional ones, include speed, ease of use and intuitiveness of operation. At the same time, the possibilities of the application deployment (such as desktop, online, enterprise) are discussed.
\end{abstract}

Klíčová slova: insights for arcgis; mpsv, trh práce; analýza trhu práce.

Keywords: insights for arcgis; molsa; labor market; labor market analysis

\section{INSIGHTS FOR ARCGIS}

Insights for ArcGIS je poměrně novou aplikací, kterou je možné provozovat $v$ rámci serverového řešení ArcGIS Enterprise nebo cloudového řešení ArcGIS Online, popř. jako desktopovou aplikaci Insights Desktop (ArcGIS Insights, 2019):

ArcGIS Insights cloud v ArcGIS Online je aplikace spustitelná ve webovém prohližeči a je licencovaná skrze předplatné ArcGIS Online. Propojení s ArcGIS Online usnadňuje přístup k datům, která jsou na ArcGIS Online publikovaná a umožňuje sdílení reportů s veřejností nebo jinými uživateli.

ArcGIS Insights v ArcGIS Enterprise je opět aplikace, která je spustitelná ve webovém prohližeči a je licencována skrze ArcGIS Enterprise licenci. Toto řešení je podobné předchozímu cloudovému řešení s tím rozdílem, že zde jsou rozšířenější možnosti správy a přístupu k datům, vrstvám a vizualizacím.

Insights Desktop je desktopovou aplikací, kterou Ize instalovat na OS Windows nebo macOS. Výhodou tohoto řešení je možnost práce bez internetového připojení. Nevýhodou zde je skutečnost, že desktopová verze má nižší funckionalitu oproti předchozím.

Obecně Insights for ArcGIS je aplikace určená pro analytickou práci s daty - obsahuje nástroje pro jejich vizualizaci prostřednictvím map, grafủ a tabulek a proces vzájemného propojení dat z různých zdrojủ je $v$ ní co nejvíc zjednodušen. 
Cílem je, aby analytik mohl prozkoumávat vztahy $\mathrm{v}$ datech, která má $\mathrm{k}$ dispozici, měl možnost $\mathrm{s}$ nimi provádět základní analýzy a připravit si je pro pokročilou analýzu např. v ArcGIS Desktop. Práce $v$ tomto nástroji je uživateli usnadněna pomocí intuitivního ovládání a to díky rozhraní „drag and drop“ (táhni a pust'). Výhodou navíc je, že výsledky práce Ize snadno sdílet na portálu a pracovní postup se ukládá jako geoprocessingový model, takže jej Ize kdykoliv opakovat (ARCDATA PRAHA, 2017).

Jak již bylo výše naznačeno, uživatelé nemusí nutně Insights for ArcGIS instalovat na svůj počítač, jelikož běží v prostředí webového prohlížeče (např. cloudové řešení).

Podporovány jsou následující webové prohlížeče:

- Microsoft Edge

- Mozilla Firefox

- Google Chrome

- macOS Safari

- iOS Safari (pouze na Tabletech)

$\checkmark$ prípadě instalace Insights Desktop je potřeba dodržet následující minimální požadavky na operační systém:

\section{Windows}

-Windows 10 (Home, Pro, and Enterprise)

-CPU: Intel Core i3 nebo AMD Athlon Dual Core procesor nebo rychlejší

-8 GB RAM

-alespoň 4 GB volné paměti na disku

-rozlišení obrazovky: 1280x768

Mac

-iMac/MacBook 2012 nebo novějši

-Mac Os 10.14 Mojave

-alespoň 4 GB volné paměti na disku

-rozlišení obrazovky: 1280x768

\section{Testovaná verze}

Byla testována verze Insights for ArcGIS 3.4 cloud v ArcGIS Online v prostředí webového prohližeče Google Chrome.

\section{Český jazyk}

Primárním jazykem je angličtina, nicméně programové prostředí Ize transformovat do mnoha jiných jazyků zahrnujících i češtinu. Nicméně se jedná pouze o jazyk prostředí aplikace, nápověda $v$ češtině $k$ dispozici není.

Jazyk aplikace je u ArcGIS Enterprise a Insights in ArcGIS Online nastaven automaticky na základě nastavení prohlížeče. $V$ prípadě Desktop verze je jazyk odvozen z jazyku operačního systému. 


\section{LICENČNÍ A CENOVÁ POLITIKA}

Cena licencí se zde odvijí jednak produktově, ale zároveň také podle typu uživatelů (ArcGIS Insights, 2019). $\checkmark$ prípadě cloudového a Enterprise řešení závisí schopnost jednotlivých členů organizace získat prístup $\mathrm{k}$ Insights for ArcGIS na oprávněních, která mají v organizaci. Oprávnění jsou určena typem uživatele, rolí a licencemi, které jsou uživateli prǐriazeny.

Uživatelé typu Viewer, Editor, a Field Worker mohou prohlížet vytvořené Insights reporty a jednotlivé stránky, které jsou $s$ těmito uživateli sdíleny. Tento typ nastavení je vhodný, pokud je vyžadován zabezpečený př́stup $\mathrm{k}$ analýzám a využitým datům.

Uživatelé typu Creator mahou využít veškeré funkce, které Insights nabízí. Mohou vytvářet nové reporty, editovat již existující, provádět analýzy, vytvářet modely a sdílet výsledky s jinými uživateli.

Uživatelé typu GIS Professional mají stejná práva jaké uživatelé typu creator s tím rozdílem, že tento uživatel má dále prístup k ArcGIS Pro aplikaci. Tento uživatel je vhodný pro ty, kteří vyžadují plnou GIS funkcionalitu pro svou práci.

Více informací k jednotlivým typům Ize získat na stránkách ArcGIS Insights:

https://doc.arcgis.com/en/insights/reference/licensing.htm.

MPSV má k dispozici v rámci ArcGIS Desktop Basic licence 60 uživatelů typu Creator. Uživatelé tohoto typu mohou vytvářet a publikovat webové mapy, sdílet je mezi sebou a $s$ veřejností a to vše $v$ cloudovém prostředí ArcGIS Online. Nicméně nástroj Insights for ArcGIS není součástí tohoto ArcGIS Online předplatného. Licenci pro tento nástroj je potřeba dokoupit. Dle ARCDATA PRAHA jedna roční licence ArcGIS for Insights stojí 15 000,- Kč bez DPH. V rámci ArcGIS Online prostředí múže MPSV tuto licenci sdílet mezi všemi uživateli typu Creator, ale je potřeba upozornit na to, že $v$ jeden čas ji může využívat pouze jeden uživatel.

Aktivaci licence může provést administrátor organizace prostřednictvím esri.com účtu. Administrátor organizace provádí také přidělení př́istupu k tomuto nástroji. Uživatel typu Creator nebo Professional může tento nástroj následně najít ve svých aplikacích po přihlášení do Portálu (viz. obrázek níže). Přímý přístup $\mathrm{k}$ tomuto nástroji je pomocí odkazu $v$ následujícím tvaru: http://mycompany.arcgis.com/apps/insights, kde mycompany je organizační URL. $V$ případě ArcGIS Online řešení je tvar odkazu následující https://www.arcgis.com/apps/insights.

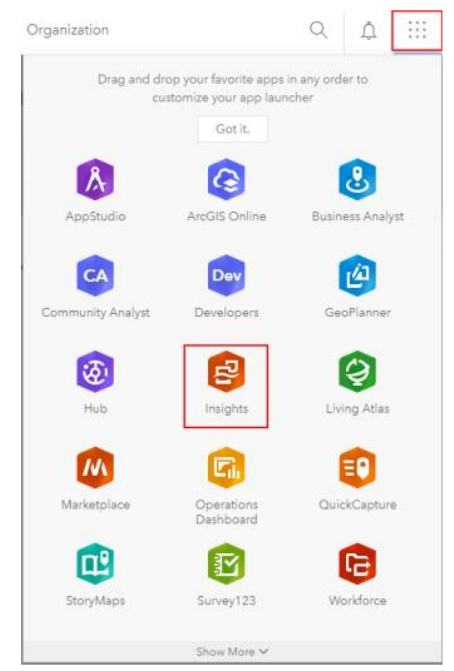

Obr. 1 Přístup a spuštění k Insights for ArcGIS 
V prípadě cloudového řešení Insights for ArcGIS v ArcGIS Online je potřeba se zmínit o kreditové politice, kterou ESRI se vznikem ArcGIS Online zavedlo. Kredity jsou ArcGIS Online měnou, které jsou uživateli účtovány za určité transakce a operace (např. uložení dat, prostorové analýzy - viz kapitola $\mathrm{k}$ analytickým operacím, geokódování atd.). Za tyto operace se tedy platí a je proto třeba zvážit, zdali je využití těchto operací nutné.

\section{POUŽÍVANÉ DATOVÉ ZDROJE A DATOVÉ FORMÁTY}

Insights pracuje primárně se souborovými daty uloženými na portálu. Vedle toho může správce definovat spojení s relačními databázemi, která pak můžeme v Insights využívat. Dále Ize také nahrávat souborová data ve formátu XLSX nebo CSV a další geodata v uložená v prostorových datových formátech.

Souhrnně jsou podporovány následující datové zdroje (ArcGIS Insights, 2019):

- Data publikovaná na ArcGIS Online jako hostované nebo registrované vrstvy

- Data z databáze ArcGIS Living Atlas

- Souborové systémy - xlsx, csv

- Prostorové datové formáty - ESRI shp, json, geojson (.zip)

- Databázové systémy - SQL Server, Oracle, PostgreSQL, SAP HANA

- ESRI Enterprise Geodatabáze

Soubory typu .dbf nelze standardně do portálu načíst. je potřeba .dbf data nejprve naimportovat do souborové geodatabáze a tu následně vypublikovat do portálu jako hostovanou vrstvu.

\section{FILOSOFIE PRÁCE}

Práce v Insights for ArcGIS je založena na vizuální exploraci dat. Aplikace využívá tzv. smart uživatelské rozhraní, které zpracuje načtená data a automatizovaně vyhodnotí jaké nástroje, metody a vizualizace jsou nejvhodnější pro daný datový soubor.

Uživatel má možnost vytvářet Insights projekty a ty organizovat do tzv. workbooků/reportů, kde uživatel může definovat spojení na data, vytvářet analýzy a vizualizace. Reporty obsahují stránky, ve kterých se provádí shromažd’ování souvisejícího obsahu. Data jsou vizualizována na stránkách $v$ tzv. kartách ve formě map, grafů a tabulek. Na data vizualizovaná $v$ těchto kartách Ize aplikovat prostorové operace. Všechny vytvořené vizualizace jsou automatizovaně vzájemně propojeny, což zvyšuje interaktivitu vytvořeného reportu.

Uživatelské rozhraní Insights for ArcGIS nabízí dva pohledy: vizualizační a procesní (modelový) pohled. Vizualizační pohled zobrazuje veškeré vizualizace, které uživatel vytvoří. Modelový pohled umožňuje uživateli si prohlédnout všechny kroky, které byly provedeny pro vytvoření dané analýzy a zároveň také mu nabízí možnost aktualizace dat či změnu některého z kroků. 


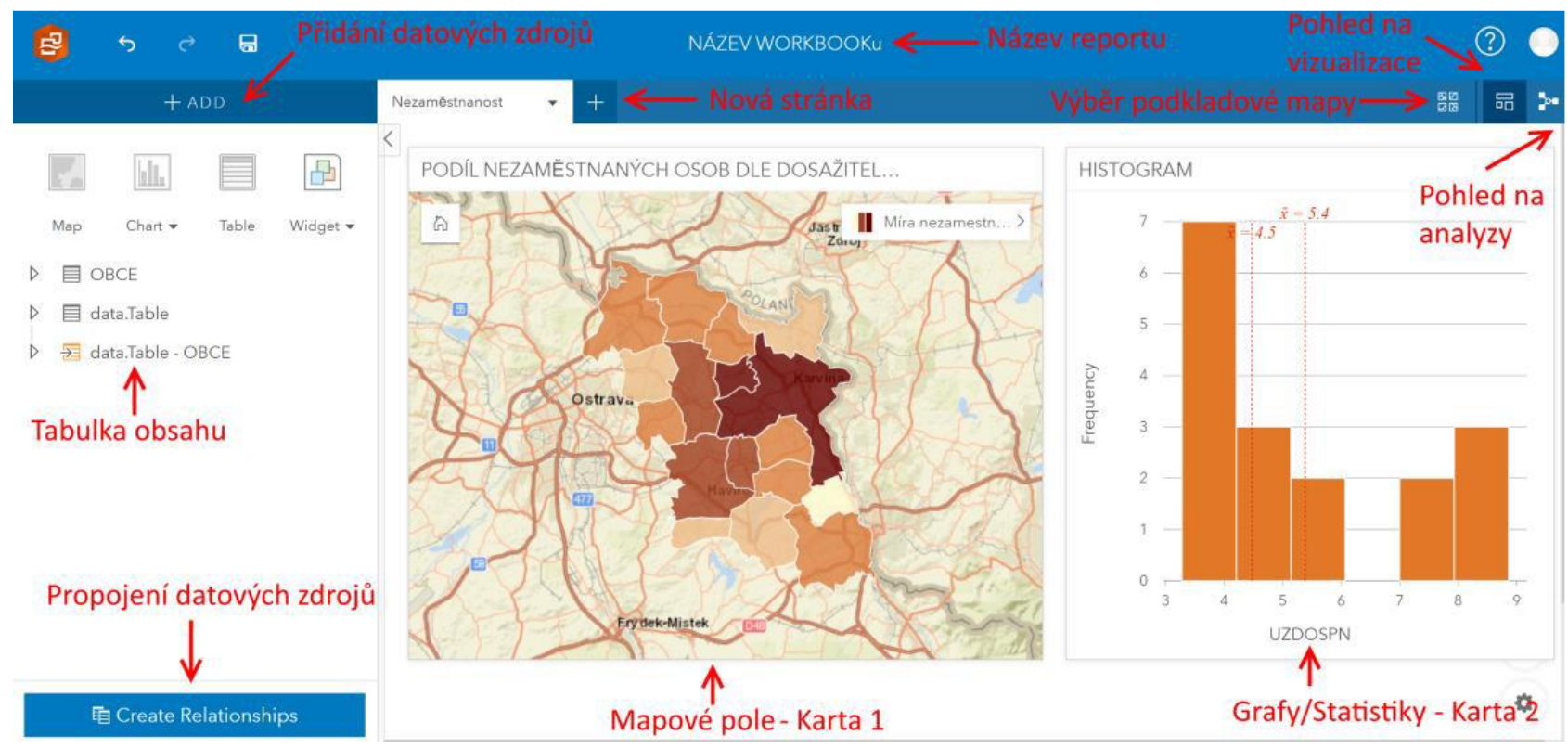

Obr. 2 Uživatelské prostředí Insights for ArcGIS (vizualizační pohled)

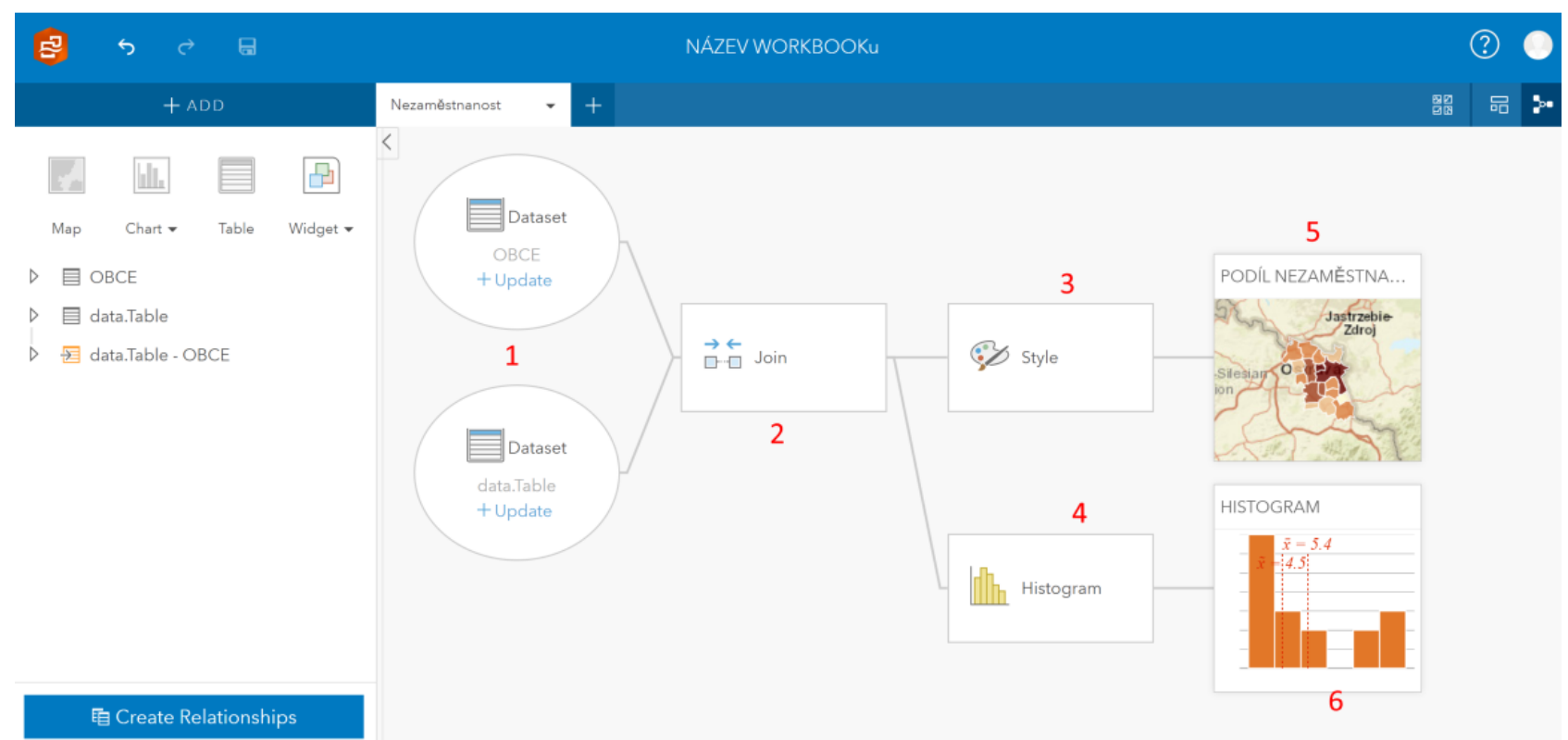

Obr. 3 Uživatelské prostředí Insights for ArcGIS (modelový pohled)

Model uvedený na obrázku výše popisuje jednotlivé kroky, které byly provedeny pro vytvoření analýzy na stránce 1, která je pojmenována jako „Nezaměstnanost“. Jednotlivé kroky:

1) Přidání datových zdrojů do analýzy.

2) Propojení načtených datových zdrojů.

3) Definice stylu zobrazení pro prostorovou vrstvu.

4) Vytvoření histogramu pro zvolený kvantitativní atribut.

5) Vykreslení mapového výstupu.

6) Vykreslení grafu. 
Data, která se do reportu přidávají, se objeví v seznamu v levé části reportu, čili v místě, kde v desktopových aplikacích tradičně bývá tabulka obsahu. $\mathrm{Na}$ tomto místě se tak nachází nástroj umožñující propojení datových zdrojů.

Nad seznamem datových vrstev Ize vidět čtyři ikony reprezentující čtyři typy vizualizace dat: mapu, graf, tabulku a média. Chceme-li některý $z$ těchto objektů vytvořit, $v$ seznamu dat zaškrtneme atributy, které chceme vizualizovat, a stiskneme příslušnou ikonu. Také můžeme atributy přetáhnout na volné místo na stránce, kde se nám automaticky objeví ikony pro tvorbu karty. Tímto způsobem snadno vytvoříme mapu vybrané vrstvy nebo graf určitého atributu. Výsledky i pracovní postupy Ize snadno sdílet s veřejností nebo jinými uživateli v organizaci.

Prozatím velkou nevýhodou Insights for ArcGIS je nemožnost zobrazení popisků prostorových prvků v mapě.

\section{GRAFICKÉ MOŽNOSTI}

Insights for ArcGIS podporuje vytvoření následujících grafických výstupů.

Tabulka 1 Mapové výstupy v Insights

\begin{tabular}{ll}
\hline Název & Význam \\
\hline Binned maps & Agregační mapy (agregace dle předdefinovaných buněk) \\
Unique values maps & Mapa jedinečných hodnot \\
Choropleth maps & Kartogram \\
Column chart symbols & Kartodiagram se sloupcovým diagramem \\
Heat maps & Mapa anomálií \\
Link maps & Pruhový kartodiagram \\
Location maps & Distribuční (lokalizační) mapy \\
Pie chart maps & Kartodiagram s výsečovým grafem \\
Graduated symbol maps & Kartodiagram \\
\hline
\end{tabular}

Tabulka 2 Grafy v Insights

\begin{tabular}{ll}
\hline Název & Význam \\
\hline Bar chart & Pruhový diagram \\
Stacked bar chart & Součtový pruhový diagram \\
Column chart & Sloupcový diagram \\
Stacked column chart & Součtový sloupcový diagram \\
Donut chart & Prstencový diagram \\
Histogram & Histogram \\
Scatter plot & Rozptylogram \\
Time series graph & Časové řady \\
Treemap & Stromová mapa \\
Bubble chart & Bublinový diagram \\
Line graph & Spojnicový graf \\
Heat chart & Diagram anomálií \\
Box plot & Krabicový diagram \\
Link chart & Spojnicový graf \\
Scatter plot matrix & Matice rozptylogramů \\
KPI card & KPI karta (Indikátor výkonnosti) \\
Combo chart & Kombinovaný graf \\
Point chart & Bodový graf \\
\hline
\end{tabular}


Podíl nezaměstnaných osob z dosažitelných uchazečů. Obce okresu Karviná 2016

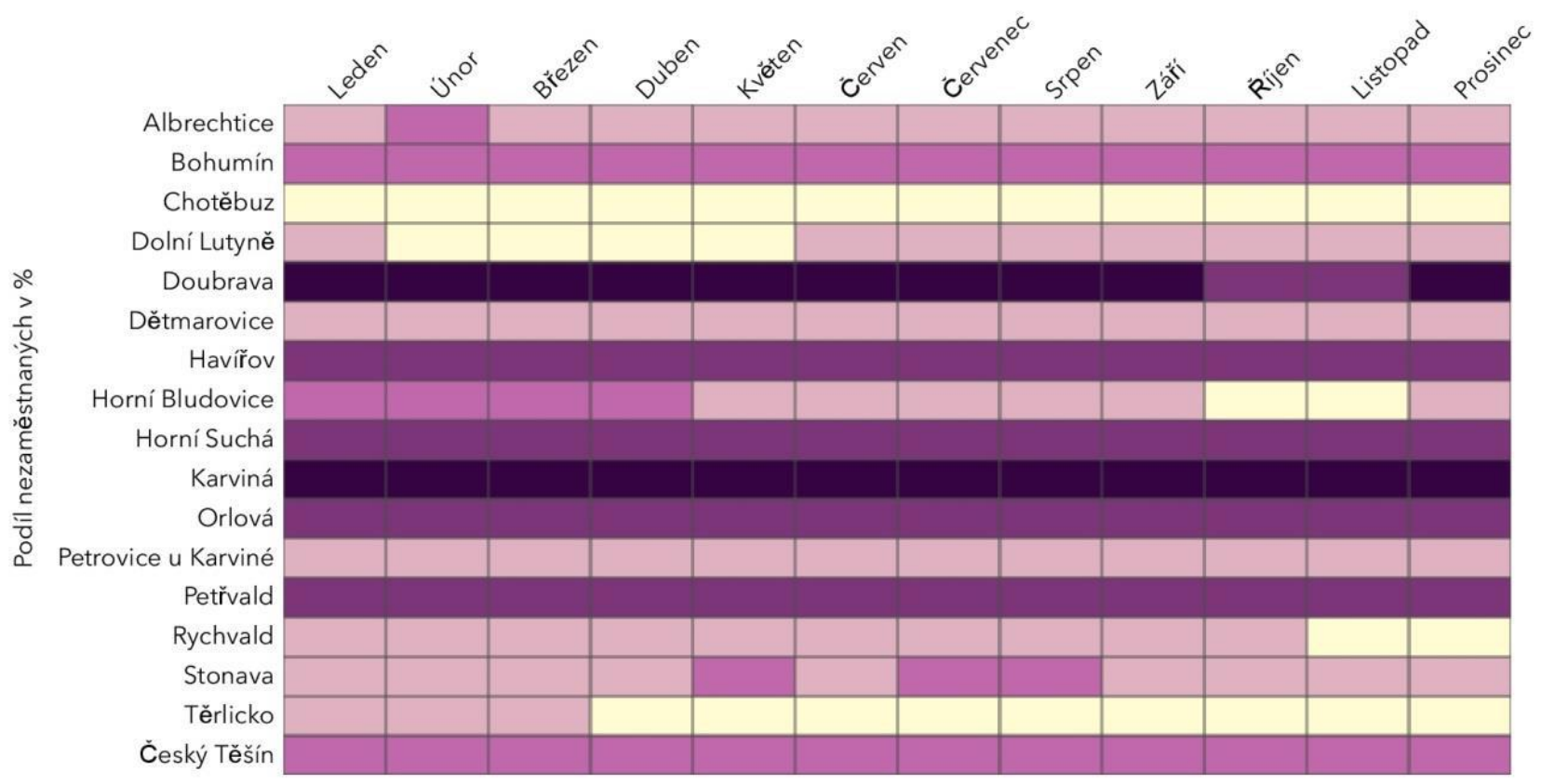

NÁZEV OBCE, MĚSÍC

Obr. 4 Ukázka diagramu anomálií (Heat graph) pro data z okresu Karviná

Dle datového typu atributu jsou jednotlivé grafy bud'to přístupné uživateli nebo jsou neaktivní.

\section{ANALYTICKÉ MOŽNOSTI}

V Insights for ArcGIS je možné si u každého zdroje dat nechat zobrazit tabulku hodnot. Je možné provést definici a výpočet nového sloupce. Pro výpočet Ize využít řadu funkcí (matematické, vyhledávací, logické atd.).

\begin{tabular}{|c|c|c|c|c|c|c|c|c|c|c|}
\hline & \multicolumn{10}{|c|}{ data.Table } \\
\hline \multicolumn{11}{|c|}{ (2) पा IR } \\
\hline NAZEV $\downarrow \uparrow$ & KOD $\downarrow \uparrow$ & OB156. $\downarrow \uparrow$ & UC & $\downarrow \uparrow$ & Uz & $\downarrow \uparrow$ & ucoo1: $\downarrow \uparrow$ & UZ001i $\downarrow \uparrow$ & UC182، & \\
\hline Albrechtice & 598925 & 2645 & & 146 & & 66 & <Žádná data〉 & <Žádná data> & <Žádná data> & $<i$ \\
\hline Bohumín & 599051 & 13725 & & 843 & & 414 & <Žádná data〉 & <Žádná data〉 & <Žádná datà & $<\dot{z}$ \\
\hline Český Tëšśn & 598933 & 16409 & & 864 & & 427 & <Žádná data〉 & <Ľádná data> & <Žádná data〉 & $<z$ \\
\hline Détmarovice & 598941 & 2884 & & 152 & & 67 & <Žádná data〉 & 《Žádná data〉 & 〈Žádná data〉 & $<z$ \\
\hline Dolní Lutynę & 598968 & 3562 & & 173 & & 71 & <Žádná datà & <Žádná datà & <Žádná data〉 & $<\dot{z}$ \\
\hline Doubrava & 568864 & 829 & & 78 & & 37 & <Źácná data > & <Žádná data > & <Žádná data〉 & $<\dot{z}$ \\
\hline Havifov & 555088 & 46919 & & 3707 & & 1796 & <Žádná data〉 & 〈Žádná data〉 & 《Žádná datà & $<z$ \\
\hline Horni Bludovice & 598178 & 1647 & & 62 & & 35 & <Žádná data> & <Žádná data> & <Žádná data> & $<z$ \\
\hline Horni Suchá & 552739 & 2953 & & 243 & & 124 & <Žáćná datà & <Žádná datà & <Ľádná datà & $<\dot{L}$ \\
\hline Chotębuz & 555291 & 897 & & 26 & & 15 & <Žádná data > & <Žádná data〉 & <Žádná data〉 & $<\angle$ \\
\hline Karviná & 598917 & 35050 & & 3354 & & 1551 & <Žádná data〉 & <Žádná data〉 & <Žádná data> & $<z$ \\
\hline Orlová & 599069 & 20021 & & 1673 & & 752 & <Žádná data〉 & <Žádná data〉 & <Žádná data〉 & $<i$ \\
\hline Petrovice u Karvin & 599077 & 3796 & & 157 & & 66 & <Žádná data> & <Žádná data〉 & 《Žádná data〉 & 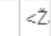 \\
\hline Petívald & 599085 & 4724 & & 282 & & 142 & <Žádná data> & <Žádná data> & <Žádná data> & $<\dot{z}$ \\
\hline \multicolumn{11}{|c|}{ Zvolené záznamy: 0 Celkem záznamú: 17} \\
\hline
\end{tabular}

Obr. 5 Tabulka dat v Insights for ArcGIS 
Statistické ukazatele se $v$ Insights for ArcGIS počítají pomocí kontingenčních tabulek. Tento nástroj umožňuje využití statistických funkcí jako napríklad aritmetický průměr (AVG), maximum (MAX), medián (MEDIAN), směrodatná odchylka (STDEV), rozptyl (VAR), 1-100 percentil (PERCENTILE). Vedle toho Ize samozřejmě využít $v$ rámci EDA a ESDA výše uvedené grafické nástroje.

Jednou z novinek roku 2019 v Insights for ArcGIS je možnost integrace skriptů Python nebo R do modelu jako součást pracovního postupu Insights. Tyto skripty mohou provádět čištění dat, jejich analýzu, statistické výpočty a vytváření nových vizualizací dat.

Insights for ArcGIS rovněž umožňuje využití prostorových analýz (viz další obrázek) jako jsou prostorové agregace, prostorové filtry, obohacení dat, výpočet hustoty, vyhledat nejbližší, vytvořit obalovou zónu/doba jízdy. Prostorové operace jako jsou prostorové agregace, vytvořit obalovou zónu/doba jízdy a výpočet hustoty však spotřebovávají kredity (viz základní informace k software).

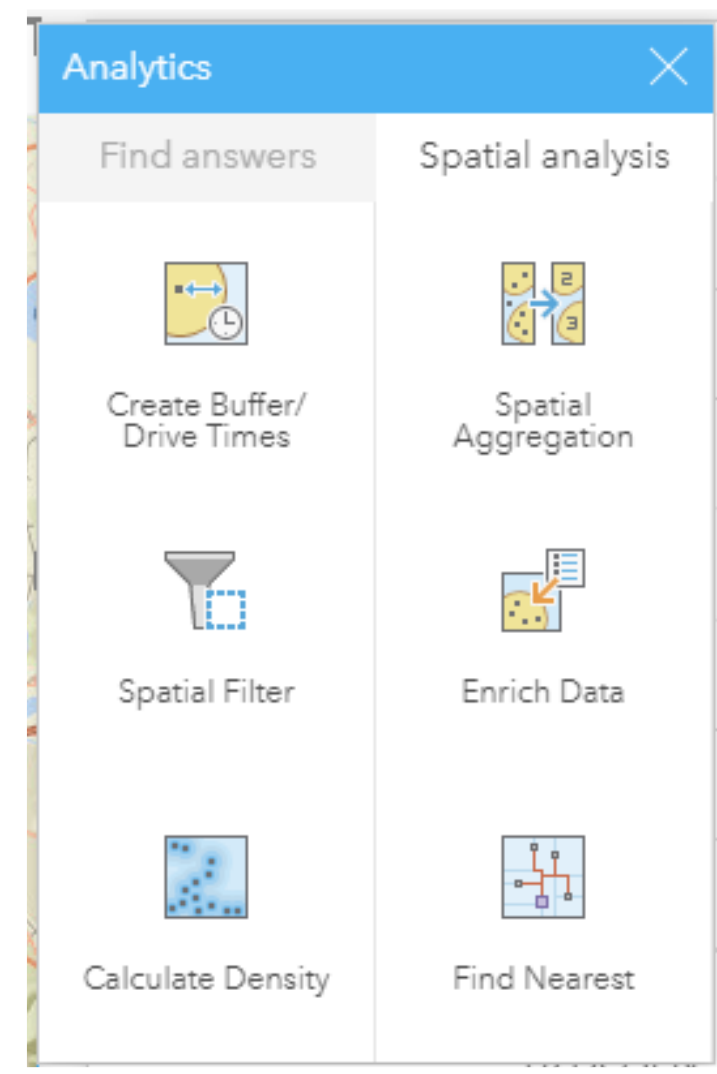

Obr. 6 Nabídka prostorových analýz v Insights for ArcGIS

\section{PREZENTAČNÍ MOŽNOSTI}

Základem práce $v$ Insights for ArcGIS je vytváření nových reportů (sešitů). Tyto reporty mohou být sdíleny $s$ veřejností nebo pouze $s$ určitými uživateli $v$ rámci organizace. Podobně mohou být sdíleny $i$ samotné stránky, modely a data. Cíloví uživatelé si pak daný report mohou prohližžet ve webovém prohližeči. $V$ reportech se mezi jednotlivými kartami automaticky vytvářejí akce, díky těmto akcím se docílí interaktivity $\mathrm{v}$ daném reportu. Vytváření animací v tomto nástroji zatím není podporováno.

\section{ULOŽENÍ NASTAVENÍ}

Celou práci a samotný report Ize uložit do Insights for ArcGIS projektu. Tento projekt je pak dostupný skrze domácí stránku Insights for ArcGIS. Součástí projektu jsou stránky, modely a reporty. Celý projekt Ize následně vyexportovat do ZIP souboru a takto může být redistribuován dalším uživatelům používající Insights for ArcGIS. Výhodou je zde propojení s ArcGIS Online, kde uživatel může vytvořené projekty spravovat a případně sdílet s dalšími uživateli nebo skupinami uživatelů. Uložený projekt obsahuje model, 
který zahrnuje veškeré kroky, kde byly pro danou analýzu provedeny. Tento model je možné uložit zvlášt' (s veškerým nastavením) a využití v jiných projektech.

\section{EXPORT REPORTU゚}

Stránky v daném reportu Ize exportovat jako statický obrázek do formátů PDF nebo jako interaktivní report do ZIP souboru. Tento souboru Ize předat cílovému uživateli, který si jej může prohlédnout a prípadně editovat $s$ využitím Insights for ArcGIS. Jinou možností prezentace výstupních analytik je uložení reportu a jeho sdílení pomocí linku. Tímto způsobem jej Ize zpřístupnit dalším uživatelům skrze webový prohližeč.

\section{UKÁZKA VYTVOŘENÍ MAPY MÍRY NEZAMĚSTNANOSTI V OKRESE}

Pro mapové zobrazení podílu nezaměstnanosti $v$ území je možné využít kartogram, kde každá příslušná územní jednotka bude rozdílně vybarvena dle místní hodnoty daného jevu.

\section{Postup tvorby vizualizace je následující:}

1) Externí tabulku s údaji (GIS statistiky) upravte (vytvořte kopii listu „OKpráce“ do nového listu „data“, odstranění prvního a posledního řádku) a uložte.

2) V prostředí Insights for ArcGIS klikněte na tlačítko "New workbook", které se nachází hned vedle vyhledávacího pole.

3) Pro přidání dat klikněte na tlačítko „+ADD“ nacházející se v levém horním rohu aplikace.

4) Po otevření nového vyskakovacího okna, vyhledejte a klikněte na položku Files (v levém panelu). Pomocí „Browse my computer" vyhledejte soubor s GIS statistikami. Ponechejte zaškrtnut pouze již dříve vytvořený list "data” a klikněte na „Add“ tlačítko.
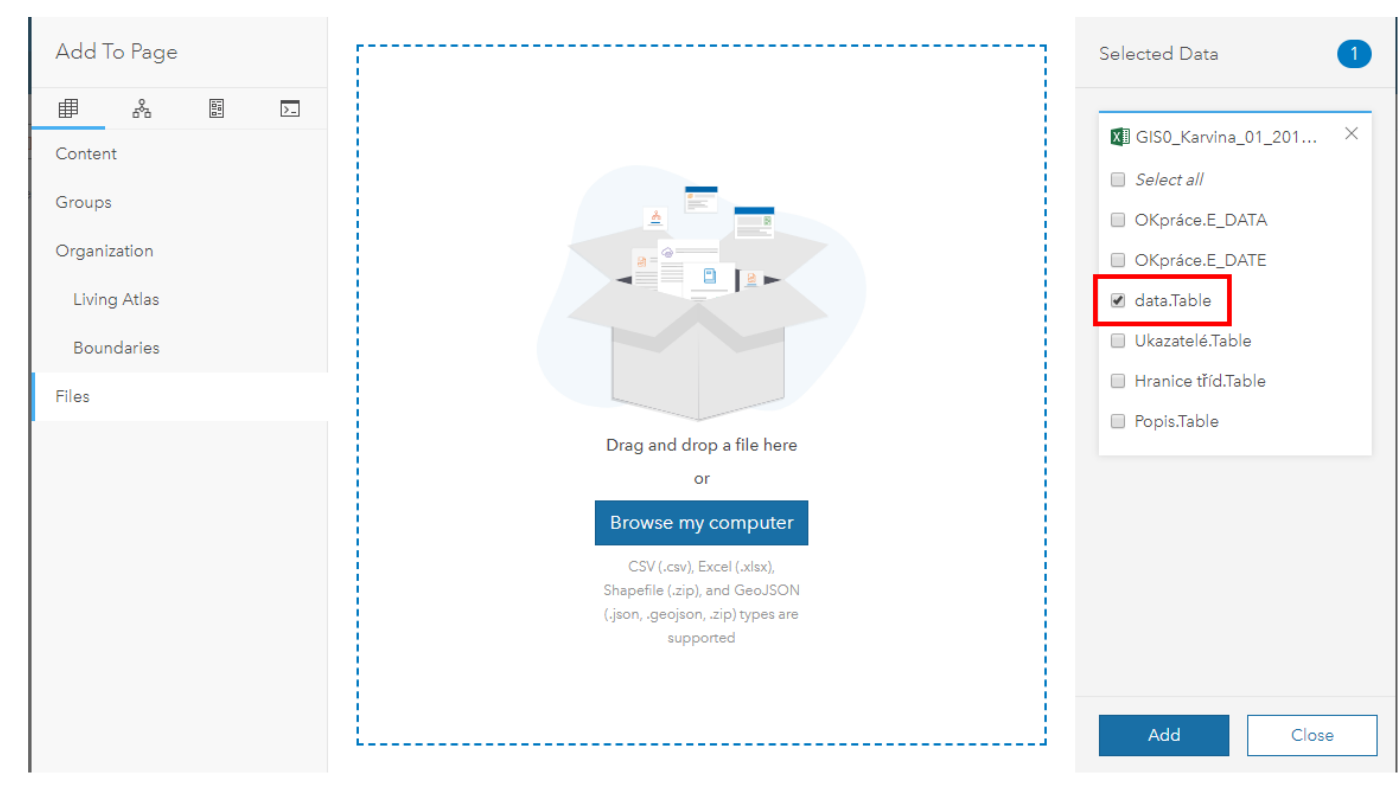

5) V seznamu atributů, které se přidaly do tabulky obsahu v reportu, vyhledejte atribut „UCDOSPN“ a přejmenujte na „Podíl nezaměstnaných v \%“ tak, jak je to naznačeno na následujícím obrázku. 


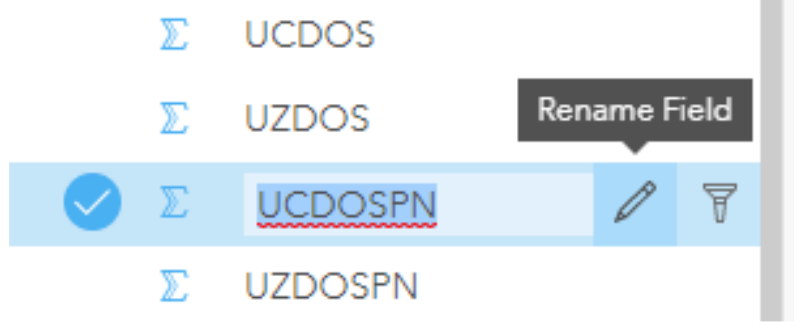

6) Nyní si prìdáme geografickou vrstvu obcí. Jelikož tuto vrstvu máme k dispozici ve formátu SHAPEFILE, je potřeba jí zabalit do ZIP souboru. Tento ZIP soubor Ize načíst do reportu stejným způsobem jako $v$ prípadě statistik.

Nyní byste měli mít k dispozici dva datové zdroje v tabulce obsahu: geografickou vrstvu obcí a tabulku se statistikami.

\section{$+A D D$}

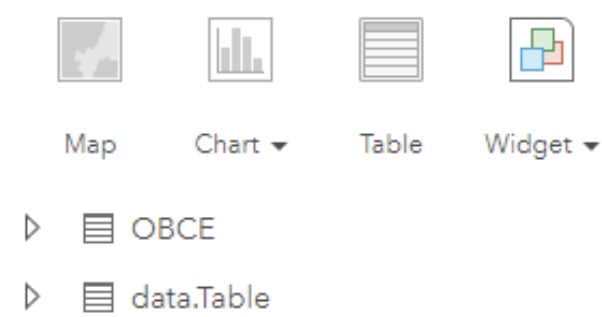

7) Oba datové zdroje je potřeba propojit, abychom pro každou územní jednotku obsaženou ve vrstvě obcí získali odpovídající hodnoty. Propojení se provede pomocí tlačítka "Create Relationshops“ nacházející se v levém dolním rohu aplikace.

Po otevření nového okna aktivujte oba datové zdroje a vyberte atribut s identifikátory, které mají oba zdroje společné. V tomto případě se jedná o „KOD“ a „KOD_OBEC“. Výběr potvrd'te tlačítkem „Finish“.

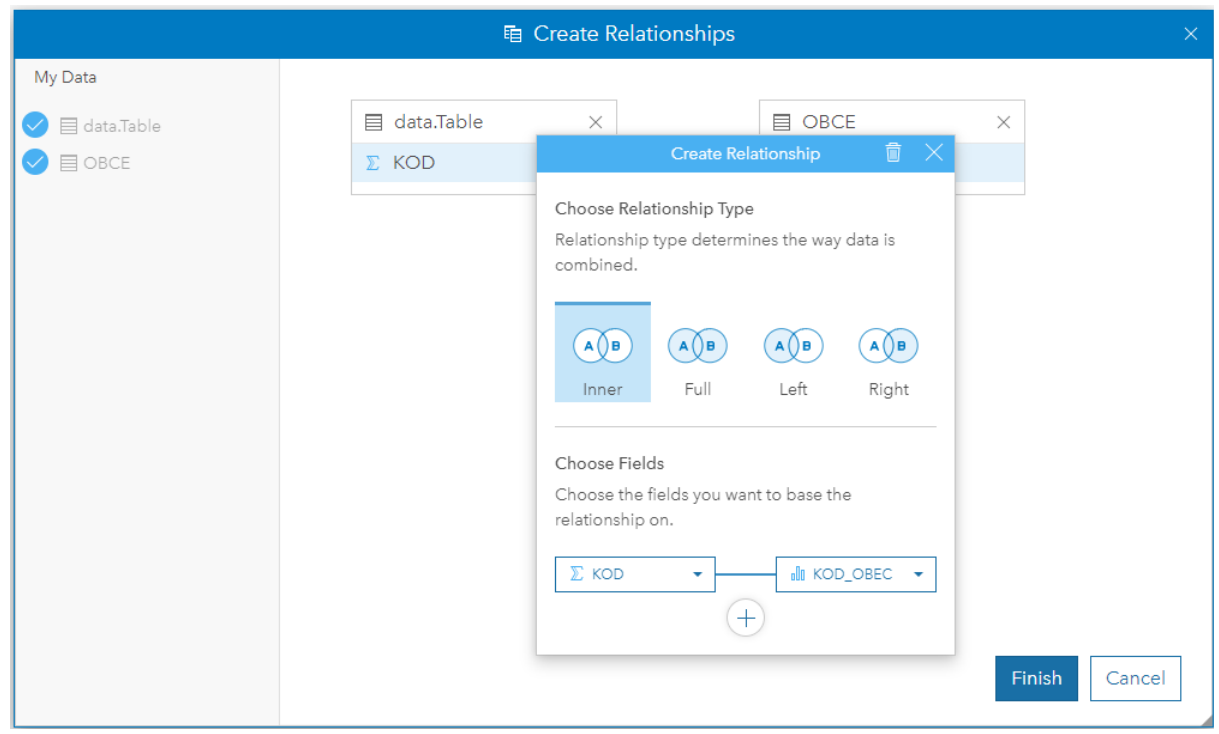

Do tabulky obsahu se Vám nyní přidala nová položka, jejíž pojmenování odpovídá názvům obou propojených datových zdrojů. 


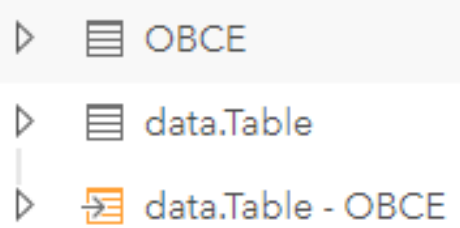

8) Nově vytvořený datový zdroj si přetažením vložte do nové stránky a vyberte možnost „Mapa”. Tímto se vytvoří nová karta.

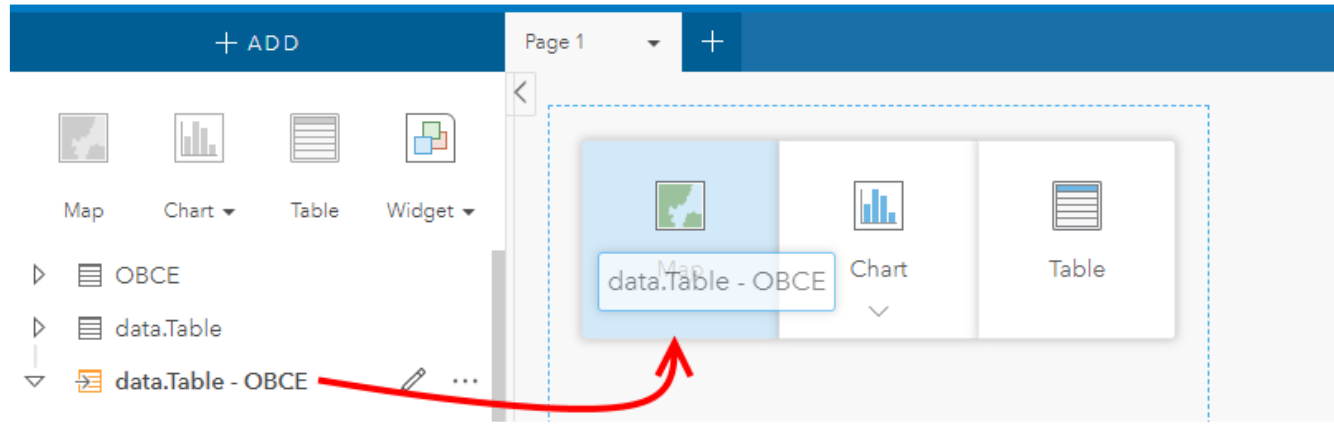

V této kartě se automaticky vygeneruje mapa zobrazující obce okresu Karviná. Všechny obce nyní mají stejný styl zobrazení tj. jednotnou barvu výplně.

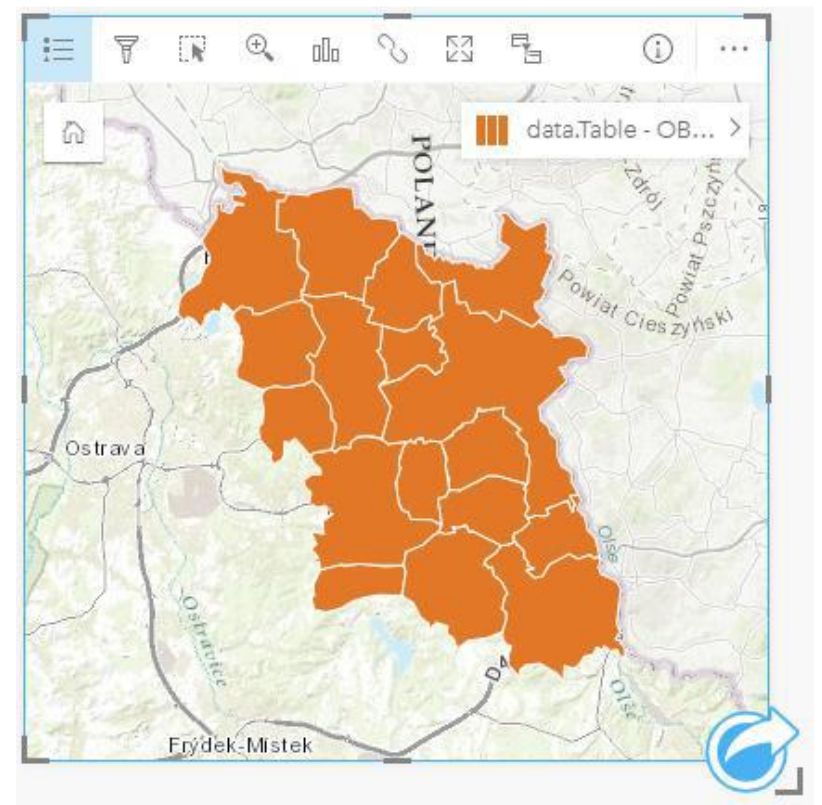

Nyní provedeme změnu stylu zobrazení tak, aby se vytvořil kartogram zobrazující míru nezaměstnanosti v území.

9) $\vee$ pravém horním rohu karty naleznete tlačítko zobrazující legendu. Klikněte na něj a vyberte možnost „Options“. V části „Style by“ vyberte atribut, kterým chceme v mapě vizualizovat „Podíl nezaměstnaných v \%“ a v části „Symbol type“ vyberte „Counts and Amounts“. Ostatní nastavení ponechejte stejné. 


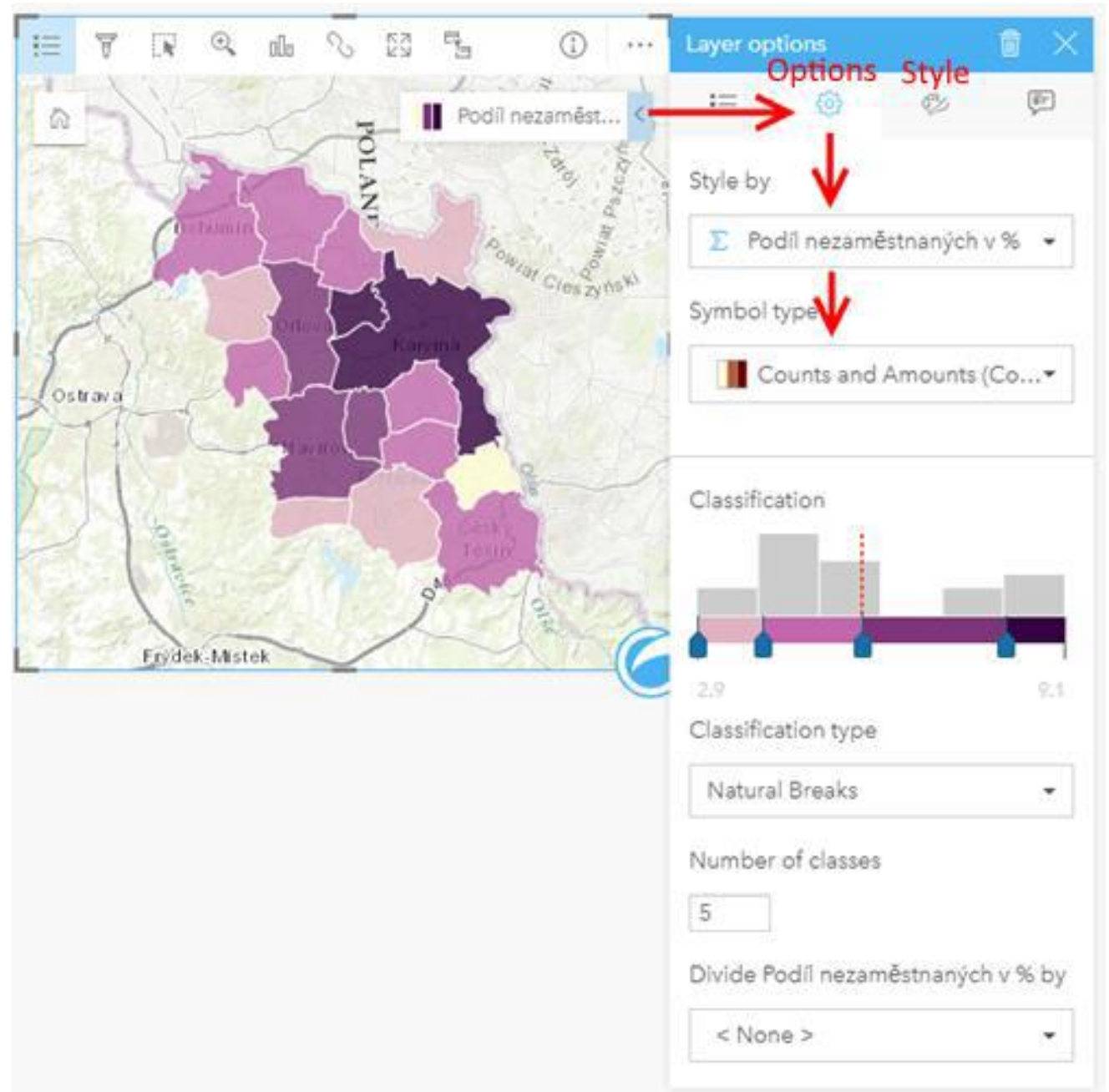

Změnu barevné stupnice Ize provést pomocí tlačítka „Style“.

10) Změna nadpisu mapy se provede jednoduchým kliknutím na nadpis Card1 a přepsáním na: „Podíl nezaměstnaných osob z dosažitelných uchazečưu.

11) Export mapového výstupu do PDF formátu Ize provést kliknutím na stránku „Page 1“ a Print Page.

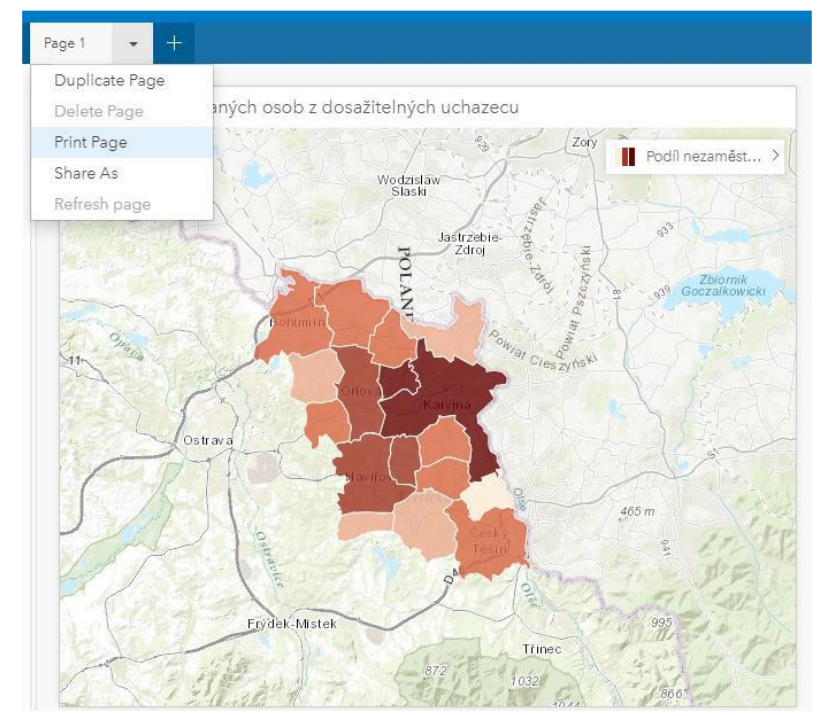




\section{LITERATURA}

ARCDATA PRAHA, 2017. ArcRevue, Časopis pro uživatele softwaru Esri a ENVI [online]. 2017- [cit. 201911-03]. https://www.arcdata.cz/media/download/1970

ArcGIS Insights př́ručka [online]. Ostrava, 2019 [cit. 2019-11-03]. Dostupné z: https://doc.arcgis.com/en/insights/reference 